\title{
The Effects of Cultivation Area and Altitude Variation on the Composition of Essential Oil of Laurus nobilis l. Grown in Eastern, Western and Central Karadeniz Region
}

\author{
Bilge YILMAZ ${ }^{* 1}$, İlhan DENIZ ${ }^{1}$
}

${ }^{1}$ Karadeniz Teknik University, Orman Faculty, Department of Forest Industry Engineering, Trabzon, Türkiye

Received: 04 May 2017 - Revised: 01 August 2017 - Accepted: 13 August 2017

\begin{abstract}
Laurus nobilis L. is one of the most valuable non-wood forest products on world export market and Turkey. Turkey is the biggest provider country for Laurus nobilis in the world. Therefore, laurel is an important commercial product for our country. In this study, the effects of cultivation area and altitude variation on essential oil content and quantity of laurel leaves were examined which grown in Trabzon, Bartın and Samsun. It was aimed to determine chemical composition of laurel's leaves grown in Karadeniz region. Laurus nobilis L. leaves were collected in three different height ranges. These were 0-100 m, 100-300 m, 300-600 m. Leaves were shade-dried and crushed. A device called 'Clevenger' was used for getting volatile oil and their yields were calculated according to dry weight. The yields of essential oils ranged between $0.91 \%$ to $1.66 \%$. These essential oils were obtained from Bartin $\left(\mathrm{B}_{2}\right)(100-300 \mathrm{~m})$ and Artvin $\left(\mathrm{A}_{1}\right)(0-100 \mathrm{~m})$ respectively. The major components of these essential oils were 1,8- cineole (19.71\%-35.63\%), $\alpha$-terpinyl acetate $(12.86 \%-21.24 \%)$, sabinene $(5.98 \%-9.40 \%)$, $\alpha$ - pinene $(3.67 \%-8.45 \%)$ and $\beta$ - pinene $(2.91 \%-5.87 \%)$ were the most abundant volatile compounds in the leaves of bay.
\end{abstract}

Keywords: Laurel, essential oils, GC-MS

\section{INTRODUCTION}

Laurel has an important product in the trade of non-wood forest products in terms of Turkey and this respect laurel plant is one of the high value-added products for our country. According to foreign trade statistics of Turkish Statistical Institute (TSI) the year of 2015, $2,207,550 \mathrm{~kg}$ of bay leaf were exported from Turkey and the financial provision corresponds to $6,365,257 \$$.

The bay, known as Laurus nobilis L., is a peculiar plant of Mediterranean Region. It belongs to Magnoliophyta (closed seeds) branch and it is in the Magnoliopsida class. Laurus nobilis which is a member of the Lauraceae family of Laurales, is a genus of Laurus [1]. The leaves are short and thick. The fresh leaves are thin and they have light green vein and they have red tinged yellow color, then their color turns into light green, with little aromatic odor. The fresh shoots are green, the next is red, black and hairless. Their maximum length is $2 \mathrm{~cm}$ [2]. The place of use of Laurus nobilis L. is, thanks to its phenolic compounds which are taking

*Corresponding Author E-mail: bilgekarasakal@gmail.com

ISSN: 2148-6905 online /C) 2017

DOI: $10.21448 / \mathrm{ijsm} .370118$ 
place in substances of laurel leaves, in food industry as natural antioxidants with antioxidant properties [3]. In particular, thanks to its volatile compounds in dried leaves, they are used in meat, soup, candy and sauce making as a flavoring [4-7]. Bay leaves and volatile oils of leaves have an effects of antiepileptic, anticonvulsive [8-10], antimicrobial [10], antibacterial [11,12].

The antibacterial effect which are found in bay leaf essential oil, thanks to the high ratio of methyl eugenol and 1,8-cineole in the bay volatile oil. Thus, they have antibacterial properties against bacteria that cause foodborne diseases such as, Staphylococcus aureus, Staphylococcus intermedius, Klebsiella neumonia, Escherichia coli O157:H7, Listeria monocytogenes, Salmonella typhimurium and Staphylococcus aureus [12, 13].

The antimicrobial effect is due to the presence of compounds such as 1,8-cineole, camphor, myrcene, $\beta$-caryophyllene, eugenol, $\alpha$-pinene, $\beta$-pinene and p-cymene in the content of volatile oil in bay leaf $[2,14]$. Apart from beneficial properties, there have lots of unique properties of bay leaf volatile oil, such as having thermal stability, does not showing phototoxic effect, positive effects against migraine, headache, high blood sugar, bacterial and fungal infections $[9,15]$. Leaf volatile oil is advised to use as a mucolytic agent (antipyretic) in advanced asthmatic disorders, upper and lower respiratory tract disorders since it has a 1,8cineole (volatile compound) in it. So it has an anti-inflammatory effect (pain, fever cutter) which is from oxygenated monoterpenes and also it is a high concentration in bay volatile oil [16]. Recent studies have shown that bay leaf and its' essential oil have a positive effect against colitis which causes flatulence in stomach [17].

In recent years, it is indicated that the high rate of volatile oil of the leaves in the southern regions of our country makes bitter taste in the bay leaves. Thus, tendency towards the bay leaves in the EU countries is shifted progress to the laurel leaves grown in Russia. These leaves have less essential oils than Mediterranean Regions. Russia is on the shore to the black sea. Therefore, the Karadeniz Region may also be a suitable region for bay exports. Based on this, Laurel leaves were collected from Artvin, Trabzon, Samsun and Bartın from Karadeniz Region and then essential oils were obtained and they were compared in oil yields and essential oil compositions.

\section{MATERIAL and METHODS}

\subsection{Plant Material}

The areas where the bay leaves were collected are given in Table 1. Laurel leaves were collected at three altitudes. These were 0-100 m, 100-300 m, 300-600 m but in Artvin $\left(\mathrm{A}_{3}\right)$ $(300-600 \mathrm{~m})$ plant material were not collected because this plant were not encountered.

Dried by leaves (11 samples of 75 gr each) were subjected to the hydro distillation for 3 hours on a Clevenger-type apparatus. The essential oils were removed from the water and stored at $4^{\circ} \mathrm{C}$ until gas chromatography-mass spectrometry (GC-MS) analysis.

Table 1. Locations and altitudes of collected laurel leaves.

\begin{tabular}{lccc}
\hline Location & \multicolumn{3}{c}{ Altitude $(\mathrm{m})$} \\
\hline & $0-100$ & $100-300$ & $300-600$ \\
Artvin & 90 & 230 & - \\
Trabzon & 20 & 200 & 600 \\
Samsun & 77 & 186 & 380 \\
Bartın & 10 & 200 & 400 \\
\hline
\end{tabular}




\subsection{GC-MS Analysis}

GC-MS analysis was carried out with a 5975 Agilent apparatus equipped with İnowax FSC column ( $60 \mathrm{~m}$ long x $0.25 \mathrm{~mm}$ i.d. $\times 10.25 \mu \mathrm{m}$ film thickness). The column temperature program was $60{ }^{\circ} \mathrm{C}$ during $10 \mathrm{~min}$, with $4{ }^{\circ} \mathrm{C} / \mathrm{min}$ increases to $220{ }^{\circ} \mathrm{C}$, then wait $10 \mathrm{~min}$ in 220 ${ }^{\circ} \mathrm{C}$ and $1{ }^{\circ} \mathrm{C} / \mathrm{min}$ increases to $240{ }^{\circ} \mathrm{C}$. The carrier gas was helium at a flow-rate of $0.8 \mathrm{ml} / \mathrm{min}$. Split mode injection (ratio 1:50) was employed. Injector temperature was $250{ }^{\circ} \mathrm{C}$. Mass spectra were taken over the $m / z 35-450$ range with an ionizing voltage of $70 \mathrm{eV}$. The relative delay times for defining the essential oil components were determined by comparing the mass spectrum profiles of the materials using Wiley GC/MS Library, Adams Library, and Mass Finder 2.1 Library mass spectrum libraries on the computer to which the device was connected [18].

\section{RESULTS and DISCUSSIONS}

\subsection{Extraction Yield}

In our study, volatile oil yield which was obtained by Hydro distillation method are shown in Table 2. The highest yield of volatile oil in our work was $1.66 \%$ Artvin $(0-100 \mathrm{~m})$ and the lowest amount was 0,91\% Bartın (100-300 m) was obtained. Our volatile oil yield results vary between $0.91 \%$ and $1.66 \%$.

Fiorini et al., investigated laurel leaf which were collected from France. They reported that the yield of laurel leaf essential was $0.57 \%$ [19]. Our results are much higher than this research.

Table 2. Avarage yield of Laurus nobilis L. essential oil.

\begin{tabular}{llcc}
\hline \multicolumn{1}{c}{ Location } & \multicolumn{3}{c}{ Avarage Yield of Essential Oil $(\mathbf{m l / 1 0 0 g r})$} \\
\cline { 2 - 4 } & $\mathbf{0 - 1 0 0 ~} \mathbf{m}$ & $\mathbf{1 0 0 - 3 0 0 ~} \mathbf{m}$ & $\mathbf{3 0 0 - 6 0 0 ~} \mathbf{m}$ \\
\hline Trabzon, $\left(\mathbf{T}_{\mathbf{1}}, \mathbf{T}_{\mathbf{2}}, \mathbf{T}_{\mathbf{3}}\right)$ & $1,33 \pm 0,0070$ & $1,58 \pm 0,0141$ & $0,99 \pm 0,1272$ \\
Bartın, $\left(\mathbf{B}_{\mathbf{1}}, \mathbf{B}_{\mathbf{2}}, \mathbf{B}_{3}\right)$ & $1,47 \pm 0,0170$ & $0,91 \pm 0,1484$ & $1,44 \pm 0,1767$ \\
Samsun, $\left(\mathbf{S}_{\mathbf{1}}, \mathbf{S}_{\mathbf{2}}, \mathbf{S}_{3}\right)$ & $0,92 \pm 0,0212$ & $1,17 \pm 0,0848$ & $1,33 \pm 0,6997$ \\
Artvin, $\left(\mathbf{A}_{\mathbf{1}}, \mathbf{A}_{\mathbf{2}}\right)$ & $1,66 \pm 0,0212$ & $1,60 \pm 0,0001$ & - \\
\hline
\end{tabular}

\subsection{GC-MS Analysis}

Fifty-six compounds accounting for $78.07 \%-98.78 \%$ of the essential oils were identified by capillary GC-MS. Components are listed in Table 3 according to their retention times. There are lots of factors affecting the production of secondary metabolites in plants. It can be explained as an environmental, geographical, physiological, genetic, political and social factors [20]. The percentage of volatile compounds also depends on climate conditions and edaphic factors. 
Table 3. The chemical composition of essential oils of leaves from laurel (Laurus nobilis L.).

\begin{tabular}{|c|c|c|c|c|c|c|c|c|c|c|c|c|c|}
\hline \multirow[t]{2}{*}{ C. $\mathbf{N}^{*}{ }^{*}$} & \multirow[t]{2}{*}{ Compound } & \multirow[t]{2}{*}{ R.T. ${ }^{* *}$} & \multicolumn{11}{|c|}{ Peak Area (\%) } \\
\hline & & & Ar1 & Ar2 & $\mathbf{T}_{1}$ & $\mathbf{T}_{2}$ & $\mathbf{T}_{3}$ & $\mathbf{S}_{1}$ & $\mathbf{S}_{2}$ & $\mathbf{S}_{3}$ & $\mathbf{B}_{1}$ & $\mathbf{B}_{2}$ & $\mathbf{B}_{3}$ \\
\hline 1 & $\alpha$-Pinene & 8.861 & 3.68 & 4.05 & 5.96 & 5.75 & 3.67 & 8.02 & 5.98 & 8.45 & 6.0 & 7.33 & 6.15 \\
\hline 2 & $\alpha$-Thujene & 8.950 & - & - & - & - & 0.37 & - & 0.76 & - & - & - & - \\
\hline 3 & Camphene & 10.568 & - & - & - & - & & 1.31 & 1.97 & 1.17 & 0.98 & 1.72 & 0.97 \\
\hline 4 & $\beta$-Pinene & 12.463 & 3.18 & 3.65 & 4.28 & 4.01 & 2.91 & 5.87 & 5.60 & 4.98 & 4.52 & 5.27 & 4.68 \\
\hline 5 & Sabinene & 13.138 & 8.0 & 9.40 & 8.53 & 7.52 & 7.44 & 6.10 & 5.98 & 6.40 & 7.31 & 7.67 & 8.56 \\
\hline 6 & Myrcene & 15.109 & - & - & 0.96 & 1.11 & 0.72 & - & - & 0.59 & 0.97 & 1.04 & 1.21 \\
\hline 7 & Phellandrene & 15.156 & 2.8 & 2.73 & - & - & - & - & - & - & - & - & - \\
\hline 9 & $\begin{array}{l}\text { Cineol (dehidro- } \\
1,8)\end{array}$ & 16.288 & - & - & - & - & - & - & 0.54 & 0.75 & - & - & - \\
\hline 10 & Limonene & 16.873 & - & - & 2.33 & 2.37 & 2.03 & 2.44 & - & - & 2.25 & 2.62 & - \\
\hline 11 & 1,8-Cineole & 17.387 & 26.54 & 34.78 & 26.42 & 19.71 & 25.92 & 35.63 & 30.90 & 28.53 & 28.67 & 24.62 & 28.71 \\
\hline 12 & $\gamma$-Terpinene & 18.968 & 0.99 & 1.32 & 1.44 & 1.45 & 1.09 & 1.93 & 1.77 & 1.79 & 1.64 & 1.37 & 1.69 \\
\hline 13 & O-Cymene & 20.100 & - & - & 0.83 & 0.98 & 1.62 & 2.55 & 3.11 & 1.50 & 0.84 & 0.85 & 0.59 \\
\hline 14 & P-Cymene & 20.109 & 1.19 & 1.06 & - & - & - & - & - & - & - & - & - \\
\hline 15 & $\begin{array}{l}\text { Cis-Sabinene } \\
\text { Hydrate }\end{array}$ & 27.602 & 0.32 & 0.45 & - & - & - & - & - & 0.48 & - & - & - \\
\hline 16 & $\alpha$ - Terpinolene & 20.608 & 0.40 & 0.50 & - & 0.53 & - & - & 0.54 & 0.57 & 0.58 & 0.51 & 0.66 \\
\hline 17 & Linalool & 30.430 & 0.99 & 2.66 & 1.45 & 2.38 & 2.98 & - & 1.35 & 1.38 & 3.06 & 3.83 & 3.38 \\
\hline 18 & Pinocarvone & 31.439 & - & - & - & - & - & - & 0.84 & - & - & - & - \\
\hline 19 & Bornyl Acetate & 31.744 & 0.50 & 0.47 & - & 0.52 & 0.44 & 2.38 & 3.44 & 2.07 & 1.24 & 1.97 & 1.77 \\
\hline 20 & $\beta$-Elemene & 32.106 & 1.89 & 0.45 & 1.56 & 1.11 & 0.73 & - & - & 0.36 & 0.47 & 0.73 & 0.58 \\
\hline 21 & 2-Undecacone & 32.220 & - & - & - & - & - & - & - & 0.43 & - & - & - \\
\hline 22 & Terpinene-4-ol & 32.389 & 4.83 & 5.27 & 5.33 & 5.84 & 4.54 & 5.03 & 3.74 & 3.46 & 4.18 & 3.29 & 3.65 \\
\hline 23 & Myrtenal & 33.374 & - & - & - & - & - & - & 0.92 & 0.63 & - & - & - \\
\hline 24 & $\delta$-Patchhoulene & 33.754 & - & - & 0.76 & - & - & - & - & - & - & - & - \\
\hline 25 & $\alpha$-Gurjunene & 33.765 & - & - & - & - & 0.58 & - & - & - & - & - & - \\
\hline 26 & $\delta$-Terpinyl Acetate & 33.917 & 2.49 & 2.52 & 1.52 & 2.53 & 1.84 & 1.56 & 1.70 & 1.57 & 1.44 & 1.45 & 1.87 \\
\hline 27 & Trans-Pinocarveol & 34.060 & - & - & - & - & - & - & 0.87 & 0.65 & - & - & - \\
\hline 28 & $\alpha$ - Humulene & 34.728 & 0.52 & - & - & 0.58 & - & - & - & - & - & - & - \\
\hline 29 & $\alpha$-Terpinyl Acetate & 35.440 & 20.73 & 20.36 & 21.24 & 18.1 & 20.86 & 20.26 & 12.86 & 17.20 & 18.28 & 18.72 & 18.03 \\
\hline 30 & Germacrene-D & 35.886 & - & - & 1.03 & & 0.49 & - & - & - & - & 0.46 & - \\
\hline 31 & Neryl Acetate & 36.043 & - & 1.06 & - & - & - & - & - & - & - & - & - \\
\hline 32 & $\begin{array}{l}\text { Lavanduly } 2 \\
\text { Methyl Butanoate }\end{array}$ & 36.046 & 1.97 & 1.06 & - & - & - & - & - & - & 0.85 & - & - \\
\hline
\end{tabular}

C.N.*:Compound number; RT. ${ }^{* *}:$ Retention time. 
Tablo 3. (Continued).

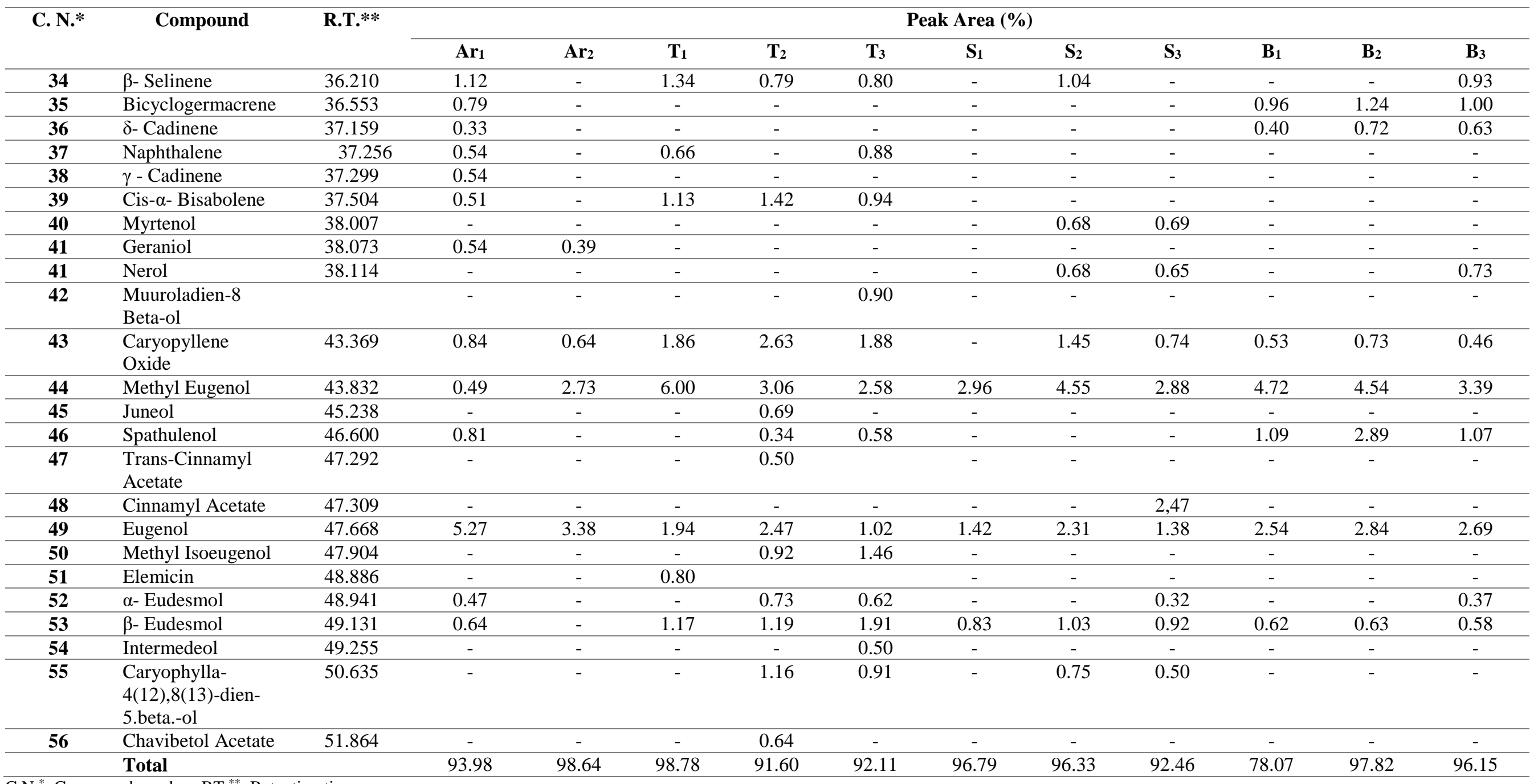

C.N. ${ }^{*}$ : Compound number; RT. ${ }^{* *}$ : Retention time. 
Our results show high similarity in Karadeniz region. The highest volatile compounds were 1,8-cineole $(19.71 \%-35.63 \%), \alpha$-terpinyl acetate $(12.86 \%-21.24 \%)$, sabinene $(5.98 \%$ $9.40 \%)$. Yilmaz et al., reported that 1.8-cineole (51.8\%), $\alpha$-terpinyl acetate $(11.2 \%)$ and sabinene $(10.1 \%)$ as the major compounds in their research which is smilar with the results of our study but results is much higher than our results [21].

GC-MS analysis of volatile oils shows that the majority of volatile oil compounds come from monoterpenes, and the majority of these monoterpenes are oxygenated monoterpenes and also Peris and Blazquez reported that oxygenated monoterpenes represented quantitatively the highest concentration of bay leaf volatile oils [22]. 1,8 cineole $(19.71 \%-35.63 \%)$, $\alpha$-terpinyl acetate $(12.86 \%-21.24 \%)$, terpinene-4-ol $(3.29 \%-5.84 \%)$, $\delta$-terpinyl acetate $(1.44 \%-2.53 \%)$ and linalool $(0.99 \%-3.83 \%)$ were the most abundant volatile compounds from oxygenated monoterpenes of our research. 1,8-cineole and $\alpha$-terpinyl acetate were found to be the most abundant volatile compounds among the oxygenated monoterpenes. The results obtained in this respect are similar to the work done by Yalçın et al., but the amount of 1,8-cineol (58.59\%) was found to be higher in the relevant study [23].

The other main compounds $\alpha$-terpinyl acetate $(12.86 \%-21.24 \%)$ is a monocyclic monoterpene. It has an ester in its structure [23]. It was reported by Chericoni et al., as a (6.0\%), Bouzouita et al., as a (11.20\%), Dadalioglu and Evrendilek, as a (16.87\%) and Ozcan and Chalcat, as a (4.04-9.87\%) [13, 24-26]. On the other hand, the second most common compound among bicyclic monoterpenes are sabinene (5.98\%-9.40\%), $\alpha$ - pinene $(3.67 \%-8.45 \%)$ and $\beta$ pinene (2.91\%-5.87\%). These were the most abundant compound as well for our research. These compounds were reported in these articles as well: Derwich et al., sabinene $(6.13 \%), \alpha-$ pinene $(3.72 \%)$ and $\beta$-pinene (3.14\%) [12], Verdian-rizi, sabinene (5.8\% -6.5\%), $\alpha$-pinene (2.6\%-3.2\%), $\beta$-pinene (2.4\%-2.9\%) [27], Chalchat et al., sabinene (7.07\%), $\beta$-pinene $(2.84 \%)$, $\alpha$-pinene (3.17\%) [28] and Moghtader and Salari, $\alpha$-pinene (\%5.25) and $\beta$-pinene (\%3.99) [29] and also linalool is a bicyclic monoterpene, was found abundant in Bartin province $(3.06 \%$ $3.83 \%$ ). It has a significant effects against several symptoms especially in convulsions [30].

Therefore, we detected some sesquiterpenes in lower amounts of our research. These are $\beta$-elemene (0.36\%-1.89\%), caryopyllene oxide (\%0.46-2.63\%), $\beta$ - eudesmol $(0.58 \%-1.91 \%)$. These compounds have been detected in several essential oils and the other oils have not been contained this compounds. These compounds have inhibitory effect on ethanol absorption [31]. Methyl eugenol $(0.49 \%-6.00 \%)$ from the phenylpraponoids was a compound that we have detected in our analysis as a high amounts. Methyl eugenol has an anesthetic and relaxing effect on muscles [23].

\section{CONCLUSION}

In this study, volatile compounds which were in the content of volatile oil in the leaves of the Laurus nobilis L. that grow in Karadeniz Region (Eastern, Western and Central), were revealed and we also aimed to determine if there is any similarity in the essential oils of laurel leaves which are grown in Karadeniz Region. We determined similarities in substances of essential oils. 1,8 cineole is the major compound but the amount of 1.8 cineole is considerably less than most of the previous studies. Since 1.8-cineole is a flavoring compound, if the compound is found in a small amount in volatile oil, it promotes that the taste of the oil can be much softer. The results of our research support, exporting laurel leaf to the EU countries from Karadeniz Region.

\section{Acknowledgement}

This study was supported by Karadeniz Technical University, Scientific Research Projects Unit (Project ID:9748) and carried out at Karadeniz Technical University, Forest Industry Engineering Department. 


\section{Conflict of Interests}

Authors declare that there is no conflict of interests.

\section{REFERENCES}

[1] Karaoğul, E., Ertaş, M., Altuntaş, E., \& Alma, M. (2011). Karadeniz ve Akdeniz Bölgesinde Yetişen Defne (Laurus nobilis)'nin Kimyasal İçeriği. I. Ulusal Akdeniz Orman ve Çevre Sempozyumu, 74-77.

[2] Yazıcı, H. (2002). Batı Karadeniz Bölgesinde Yetişen Defne (Laurus nobilis L.) Yaprak ve Meyvelerinden Faydalanma İmkanlarının Araştırılması. Zonguldak Karaelmas Üniversitesi. Fen Bilimleri Enstitüsü, Yayınlanmamış Doktora Tezi, 309.

[3] Muñiz-Márquez, D. B., Rodríguez, R., Balagurusamy, N., Carrillo, M. L., Belmares, R., Contreras, J. C., ... \& Aguilar, C. N. (2014). Phenolic content and antioxidant capacity of extracts of Laurus nobilis L., Coriandrum sativum L. and Amaranthus hybridus L. CyTAJournal of Food, 12(3), 271-276.

[4] Arctander, S. (2017). Perfume and flavor materials of natural origin. Lulu. com.

[5] Pruthi, J. S. (1998). Spices and condiments (No. Ed. 5). National Book Organisation Publishers and Distributors.

[6] Timur, M. (2001). Defne Yağ Veriminin Arttırılması ve Bileşiminin Gaz Kromatografi Cihazı ile Belirlenmesi. Mustafa Kemal Üniversitesi, Fen Bilimleri Enstitüsü Yüksek Lisans Tezi.

[7] Quijano, C. E., \& Pino, J. A. (2007). Characterization of the leaf essential oil from laurel (Laurus nobilis L.) grown in Colombia. Revista CENIC. Ciencias Químicas, 38(3), 371374.

[8] Simić, M., Kundaković, T., \& Kovačević, N. (2003). Preliminary assay on the antioxidative activity of Laurus nobilis extracts. Fitoterapia, 74(6), 613-616.

[9] Sayyah, M., Saroukhani, G., Peirovi, A., \& Kamalinejad, M. (2003). Analgesic and antiinflammatory activity of the leaf essential oil of Laurus nobilis Linn. Phytotherapy Research, 17(7), 733-736.

[10] Kang, H. W., Yu, K. W., Jun, W. J., Chang, I. S., Han, S. B., Kim, H. Y., \& Cho, H. Y. (2002). Isolation and characterization of alkyl peroxy radical scavenging compound from leaves of Laurus nobilis. Biological and Pharmaceutical Bulletin, 25(1), 102-108.

[11] Özcan, M., \& Erkmen, O. (2001). Antimicrobial activity of the essential oils of Turkish plant spices. European Food Research and Technology, 212(6), 658-660.

[12] Derwich, E., Benziane, Z., \& Boukir, A. (2009). Chemical composition and antibacterial activity of leaves essential oil of Laurus nobilis from Morocco. Australian Journal of Basic and Applied Sciences, 3(4), 3818-3824.

[13] Dadalioğlu, I., \& Evrendilek, G. A. (2004). Chemical compositions and antibacterial effects of essential oils of Turkish oregano (Origanum minutiflorum), bay laurel (Laurus nobilis), Spanish lavender (Lavandula stoechas L.), and fennel (Foeniculum vulgare) on common foodborne pathogens. Journal of agricultural and food chemistry, 52(26), 82558260 .

[14] Tanker, M., \& Tanker, N. F. (1990). Cilt 2. Ankara: Ankara Üniversitesi Basımevi.

[15] Polovka, M., \& Suhaj, M. (2010). Detection of caraway and bay leaves irradiation based on their extracts' antioxidant properties evaluation. Food chemistry, 119(1), 391-401.

[16] Juergens, U. R., Engelen, T., Racké, K., Stöber, M., Gillissen, A., \& Vetter, H. (2004). Inhibitory activity of 1, 8-cineol (eucalyptol) on cytokine production in cultured human lymphocytes and monocytes. Pulmonary pharmacology \& therapeutics, 17(5), 281-287. 
[17] Matsuda, H., Shimoda, H., Ninomiya, K., \& Yoshikawa, M. (2002). Inhibitory mechanism of costunolide, a sesquiterpene lactone isolated from Laurus nobilis, on blood-ethanol elevation in rats: involvement of inhibition of gastric emptying and increase in gastric juice secretion. Alcohol and Alcoholism, 37(2), 121-127.

[18] Polatoğlu, K., Demirci, B., Demirci, F., Gören, N., \& Başer, K. H. C. (2012). Biological activity and essential oil composition of two new Tanacetum chiliophyllum (Fisch. \& Mey.) Schultz Bip. var. chiliophyllum chemotypes from Turkey. Industrial crops and products, 39, 97-105.

[19] Fiorini, C., Fouraste, I., David, B., \& Bessiere, J. M. (1997). Composition of the Flower, Leaf and Stem Essential Oils from Laurus nobilis. Flavour and fragrance journal, 12(2), 91-93.

[20] Figueiredo, A. C., Barroso, J. G., Pedro, L. G., \& Scheffer, J. J. (2008). Factors affecting secondary metabolite production in plants: volatile components and essential oils. Flavour and Fragrance journal, 23(4), 213-226.

[21] Yilmaz, E. S., Timur, M., \& Aslim, B. (2013). Antimicrobial, antioxidant activity of the essential oil of Bay Laurel from Hatay, Turkey. Journal of Essential Oil Bearing Plants, 16(1), 108-116.

[22] Peris, I., \& Blázquez, M. A. (2015). Comparative GC-MS analysis of bay leaf (Laurus nobilis L.) essential oils in commercial samples. International journal of food properties, 18(4), 757-762.

[23] Yalçın, H., Anık, M., Şanda, M. A., \& Çakır, A. (2007). Gas chromatography/mass spectrometry analysis of Laurus nobilis essential oil composition of Northern Cyprus. Journal of medicinal food, 10(4), 715-719.

[24] Chericoni, S., Prieto, J. M., Iacopini, P., \& Morelli, I. (2005). Essential oils of commonly used plants as inhibitors of peroxynitrite-induced tyrosine nitration. Fitoterapia, 76(5), 481-483.

[25] Bouzouita, N., Nafti, A., Chaabouni, M. M., Lognay, G. C., Marlier, M., Zghoulli, S., \& Thonart, P. (2001). Chemical composition of Laurus nobilis oil from Tunisia. Journal of essential oil research, 13(2), 116-117.

[26] Özcan, M., \& Chalchat, J. C. (2005). Effect of different locations on the chemical composition of essential oils of laurel (Laurus nobilis L.) leaves growing wild in Turkey. Journal of medicinal food, 8(3), 408-411.

[27] Verdian-rizi, M. (2009). Variation in the essential oil composition of Laurus nobilis L. of different growth stages cultivated in Iran. Journal of Basic and Applied Sciences, 5(1), 33-36.

[28] Chalchat, J. C., Özcan, M. M., \& Figueredo, G. (2011). The composition of essential oils of different parts of laurel, mountain tea, sage and ajowan. Journal of Food Biochemistry, 35(2), 484-499.

[29] Moghtader, M., \& Salari, H. (2012). Comparative survey on the essential oil composition from the leaves and flowers of Laurus nobilis L. from Kerman province. Journal of Ecology and the Natural Environment, 4(6), 150-153.

[30] Santos, F. A., \& Rao, V. S. N. (2000). Antiinflammatory and antinociceptive effects of 1, 8 -cineole a terpenoid oxide present in many plant essential oils. Phytotherapy research, 14(4), 240-244.

[31] Yoshikawa, M., Shimoda, H., Uemura, T., Morikawa, T., Kawahara, Y., \& Matsuda, H. (2000). Alcohol absorption inhibitors from bay leaf (Laurus nobilis): structurerequirements of sesquiterpenes for the activity. Bioorganic \& medicinal chemistry, 8(8), 2071-2077. 